(ख) $w$

ISSN 2450-6486

www.ehs-ss.pl

DOI: 10.38014/ehs-ss.2020.3-1.12

Богдан ЧЕРНЯВСЬКИЙ

\title{
Теоретичні основи формування у майбутніх економістів вмінь дінгво-самоосвіти
}

\begin{abstract}
BOGDAN CHERNYAVSKY. Theoretical bases of formation of skills of linguistic and self-education in future economists. The article reveals the essence of linguistic self-education, analyzes the features of linguistic self-educational activity of future economists. A list of skills that ensure the effectiveness of the linguistic and self-educational activities of future economists is highlighted and characterized, foreign experience of their formation is highlighted.

Keywords: linguistic self-education, future economists, linguistic education of future economists, skills of linguistic self-education, training.
\end{abstract}

Постановка проблеми. В умовах інтеграції та глобалізації вітчизняного освітнього простору суттевих змін зазнає професійна підготовка майбутніх фахівців економічної галузі. Аналіз стандартів вищої освіти дає підстави констатувати, що ії невід'ємною складовою є формування готовності майбутнього економіста до міжкультурної комунікації іноземною мовою. В той же час, результати вивчення стану іншомовної підготовки студентів в закладах вищої освіти, результати власного досвіду викладацької діяльності, свідчать 
про недостатність виділеного часу на мовні дисципліни. Відтак, результативність дінгвоосвіти майбутніх економістів більшою мірою базується на їх лінгвосамоосвітній діяльності і залежить від рівня сформованості відповідних вмінь.

Метою цієї статті є визначення сутності вмінь дінгвосамоосвіти майбутніх економістів й характеристика основних напрямків їх розвитку в процесі професійної підготовки у закладах вищої освіти.

Виклад основного матеріалу. Результати здійсненого аналізу наукових джерел, дають підстави зазначити, що лінгвосамоосвіта $є$ інтеградьним поняттям, що поєднує аспекти «освіта», самоосвіта» та «лінгвістична освіта», які є базою нашого дослідження.

У широкому сенсі поняття «освіта» розуміється як соціальна практика, орієнтована на культурне відтворювання [17, с. 405]; духовне обличчя дюдини, яке складається під впливом моральних і духовних цінностей, що є надбанням її культурного кола, а також процес виховання та самовиховання, де провідним є не обсяг знань, а поєднання останніх з особистісними якостями та вміння самостійно ними розпоряджатися [17, с. 405].

У вузькому розумінні «освіта» - це процес засвоєння індивідом систематизованих знань, умінь і навичок, формування на їх основі наукового світогляду, розвиток властивостей особистості, іiі творчих сил і здібностей [8, с. 30]. Результатом такого процесу є освіченість особистості.

За визначенням, прийнятим Генеральною конференцією ЮНЕСКО, під освітою розуміється процес і результат удосконалення здібностей і поведінки особистості, при якому вона досягає соціальної зрілості та індивідуального зростання [5, с. 241].

Однією з основних складових освіти є поняття «самоосвіта», яке, на думку вчених, є найвищим ступенем освіти.

3 позицій філософії, самоосвіта - це пізнавальний процес, який підпорядковано основним закономірностям теорії пізнання та результатом якого є нові знання [17, с. 450].

Соціологічна наука розуміє самоосвіту як діяльність певної особистості або соціальної групи, характеристиками якої виступають спрямованість на задоволення потреб у соціалізації, самореалізації, а також самостійне підвищення освітнього, наукового, професійного та культурного рівнів [14, с. 283]

В педагогічній теорії існують різні визначення даного феномену, серед них такі, де «самоосвіта» розуміється як: 
- самостійна освіта, отримання системних знань у певній галузі науки, техніки, культури, професійної сфери, яка передбачає безпосередній інтерес особистості в органічному поєднанні із самостійністю у вивченні матеріалу (Н. Сидорчук) [12, с. 254].

- самостійна пізнавадьна діяльність дюдини, спрямована на досягнення певних особистісно значимих освітніх цілей, задоволення загальнокультурних запитів, стимулювання пізнавальних інтересів будь якої сфери діяльності, підвищення та вдосконалення професійної кваліфікації (О. Антонова) [1]

- цілеспрямований процес самостійного оволодіння цілісною системою знань та вмінь, поглядів і переконань, прогресивним досвідом у певній галузі діяльності під впливом особистих і суспільних інтересів (М. Касьяненко) [10, с. 75];

- особлива діяльність зі специфічною структурою, яка відрізняеться від навчальної діяльності та ї самостійних форм основними компонентами - мотивами, завданнями, способами дій і контролю, що визначаються самим студентом (А. Маркова) [10, с. 75];

Систематизуючи та узагальнюючи погдяди дослідників, в нашому дослідженні під самоосвітою майбутніх економістів будемо розуміти пізнавальний процес, метою якого є самостійне набуття певних знань професійної сфери, опанування, осмислення та засвоєння теоретичної бази, набуття та вдосконалення відповідних умінь та навичок, необхідних для здійснення якісної професійної діяльності.

3 боку іншомовної освіти здатність до самоосвіти - це інтегральна характеристика особистості, що свідчить про иї готовність та здатність самостійно підтримувати та покращувати рівень володіння іноземною мовою. Зазначене зумовлює виокремлення терміну «дінгвасамоосвіта», що, за словами І. Бобикіної, є кумулятивною здатністю й готовністю студента самостійно здійснювати цілеспрямовану систематичну дія льність щодо розвитку особистісних якостей, вдосконалення власної іншомовної освіти або задоволення пізнавальних потреб за допомогою іноземної мови [3].

Проаналізувавши та узагальнивши погляди дослідників на феномен «дінгвосамоосвіти» загалом, в нашому дослідженні під поняттям «дінгвосамоосвіта майбутніх економістів» будемо розуміти цілеспрямовану пізнавальну діяльність, яка здійснюється студентом, 3 метою овододіння іноземною мовою, набуття спеціальних знань, 
професійних мовних, мовденнєвих та комунікативних вмінь та навичок, необхідних і достатніх для ведення професійної іншомовної комунікації.

Отже, відповідно до наведеного визначення стає зрозумілим, що розвиток вмінь дінгвосамоосвіти може відбуватися дише під час дінгвосамоосвітньої діяльності.

Лінгвосамоосвітня діяльність майбутніх економістів підпорядковується загальній теорії діяльності, що досить повно висвітлена в науковій літературі. Фундаментальними засадами теорії діяльності є наступні:

- діядьність - активний, цілеспрямований процес відображення реальних зв' язків та відносин суб'єкта з об'єктивною дійсністю (К. Есипович) [6];

- д діяльність має три сторони: мотиваційну, цільову та виконавчу; мотиваційна сторона полягає у взаємодії потреб, мотивів та цілей як «майбутнього результату діяльності»; цільова сторона спрямована на дослідження умов діяльності, виокремлення предмету діяльності, розкриття його характеристик; виконавча сторона - це сукупність певних дій та операцій, за допомогою яких здійснюється діяльність та досягається кінцева мета (О. Деонтьєв) [9] .

Отже, дінгвосамоосвітня діяльність майбутнього економіста - це цілеспрямований процес індивідуальної пізнавальної активності, спрямованої на формування та вдосконалення вмінь іншомовного спілкування з орієнтацією на майбутню професійну діяльність.

Будь-яка діяльність, у тому числі й дінгвосамоосвітня, має свою структуру, одним з найваждивіших компонентів якої $є$ певні дії та операції, побудовані на необхідних для них вміннях. Тож стає зрозумілим, що для здійснення дінгвосамоосвітньої діяльності студенти-економісти мають володіти певним набором вмінь, оскільки саме уміння оперувати отриманими лінгвосамоосвітніми знаннями у внутрішньому плані своєї індивідуальної свідомості може дати майбутньому фахівцю можливість отримувати ситуативні і перспективні відомості про об'єкти та загальне соціальне середовище іноземною мовою, мождивість передбачити наслідки свого професійного спілкування, планувати свою професійну комунікативну діяльність, формувати індивідуально-особистісне уявлення про картину світу іноземною мовою тощо і формувати власний стиль комунікативної поведінки [11]. 
Щодо дінгвосамоосвітніх вмінь, то вони складають комплекс самостійних пізнавальних дій, спрямованих на вирішення певних завдань на базі сформованих знань дінгвосамоосвітньої діяльності.

Під уміннями лінгвасамоосвіти майбутніх економістів ми розуміємо здатність останніх до здійснення дінгвасамоосвітньої діяльності, спрямованої на самостійне опанування мовою в обсязі, необхідному для здійснення ефективної міжкультурної комунікації в професійній галузі.

Спираючись на концепції вітчизняних та зарубіжних вчених, виокремлюємо таку низку лінгвасамоосвітніх вмінь [3]: уміння аутометодичної мотивації; уміння планування; уміння реалізації лінгвасамоосвітньої діяльності; уміння контролю; більш узагальнений перелік вмінь самоосвіти можна зобразити так: організаційні (вміння самостійно ставити цілі лінгвасамоосвітньої діяльності та планувати ії згідно з вимогами професійної сфери); інформаційно-аналітичні (вміння здійснювати пошук і вибір джерел інформації для подальшої роботи, вміння знаходити і застосовувати спеціалізовані програмні засоби за допомогою електронних ресурсів); рефлексивні (вміння самостійно оцінювати результат своєї діяльності відповідно до цілей і завдань) [2].

На думку багатьох дослідників, під час формування вмінь дінгвосамоосвіти майбутніх економістів необхідно також зважати на сфери комунікативної діяльності, теми та ситуації, мовленнєві діï, що враховують професійну спрямованість студентів; мовний матеріал (фонетичний, лексичний, граматичний, орфографічний), правила його оформлення й оперування ним; комплекс спеціальних (мовленнєвих і комунікативних) умінь, що характеризують рівень практичного оволодіння іноземною мовою як засобом спілкування, в тому числі в інтеркультурних ситуаціях; систему знань національнокультурних особливостей і реалій країни, мова якої вивчається; навчадьні та адаптивні вміння, раціонадьні прийоми розумової праці, що забезпечують культуру засвоєння мови в навчальних умовах і культуру спілкування з його носіями [4, с. 165].

Оскільки однією із стратегічних цілей в умовах інтеграції в світовий освітній простір стає розвиток активної особистості, здатної бути суб'єктом своєї діяльності, ефективно навчатися протягом усього життя і взаємодіяти в професійній діяльності в мультилінгвальному і полікультурному суспільстві, увага до формування вмінь лінгвосамоосвіти ставала об'єктом вітчизняних та закордонних вчених, науковців, методистів. 
За словами А. Шелтена, в зарубіжній вищій школі історично склалася специфічна концепція щодо організації лінгвосамоосвіти студентів, яка реалізуеться двома пов'язаними між собою етапами: початковим та просунутим [21, с. 141]. На початковому етапі навчання мови дві третини навчального часу становить самостійна робота студентів 3 різноманітними джерелами та матеріалом. Проте така робота чітко планується і контролюється. Саме на цьому етапі проходить процес набуття студентами вмінь, необхідних для здійснення подальшої самостійної дослідницької роботи. Далі при переході 3 курсу на курс, система організації процесу навчання змінюється, як змінюється і відсоток матеріалу, що залишається на самостійне опанування.

У багатьох університетах Европи навчання будується не традиційно (декція або практичне заняття), а у в вигдяді роботи над дослідницьким проектом, який повинен бути створений іноземною мовою. При цьому проект передбачає самостійне вирішення реальної проблеми на міждисциплінарному рівні. Залучення студентів до подібної дослідницької роботи може відбуватися на просунутому етапі навчання. Наприклад, в закладах вищої освіти Німеччини виконання науково-дослідних робіт іноземною мовою $є$ основою навчання студентів будь-яких спеціадьностей.

Дослідження системи вищої освіти в США свідчать, що вона заснована на організації самоосвіти студентів. Звідси обгрунтована поява «відкритого навчання», «відкритих університетів», де студента можуть вільно визначити свої науково-дослідницькі інтереси і в діалозі з викладачами висловлювати різні думки, критично аналізувати наукові позиції. Будь-яка повноцінна підготовка до семінарів, й 3 мови зокрема, в університетах США передбачає фактично мікродослідження, що вимагає від студентів певного часу продуктивної і творчої роботи 3 джерелами свіжої наукової періодики в самостійному режимі або складання студентами есе 3 відповіддю на запитання, запропоноване викладачем.

Також в закладах вищої освіти США й Европи для формування у студентів вмінь самоосвіти, й дінгвасамоосвіти зокрема, досить широко використовується гнучке поєднання асинхронного (індивідуального) і синхронного (спільного) навчання. Низка вишів США й Західної Европи активно використовує інтегроване / змішане навчання (blended learning), яке містить поєднання різних методик і схем управління процесом навчання: навчання в аудиторії, 
дистанційне навчання, синхронне дистанційне навчання [16] частина занять здійснюеться в аудиторії під керівництвом викладача, а частина - самостійно. Організація змішаного навчання спирається на положення синергетичного, діяльнісного, творчого, інноваційного підходів та принципи наявності засобів створення інтерактивного діалогу, комп'ютерної візуалізації навчального матеріалу [18].

Поширеною формою самоосвіти й лінгвасамосвіти зокрема в закладах вищої освіти США, Канади, Німеччини, Франції та ін. є електронне навчання (e-learning), що передбачає різні способи отримання знань із застосуванням інформаційних технологій: дистанційного навчання, мобільного навчання 3 використанням мобільних пристроїв, віртуального навчання $[15,16]$.

Значної уваги в багатьох зарубіжних університетах приділяеться посиленню поєднання навчання 3 професійною практикою на підприємствах на батьківщині та за кордоном, саме тому зросли й вимоги до володіння іноземними мовами, опанування якими здійснюється саме в процесі живої комунікації під час професійної практики. В освітньому процесі США та Німеччини добре зарекомендувала себе і отримала поширення «дуальна система» [13], що передбачає одночасне навчання студентів в університеті (два три дні на тиждень) і на підприємстві. Наприклад, у Гарвардській школі бізнесу (ГШБ) ця система отримала назву «польове» навчання (Field Studies) та передбачала практику у провідних економічних бізнес-компаніях і некомерційних організаціях. Базисом такого навчання стають саме вміння самоосвіти в цілому і лінгвасамоосвіти як іï складової, оскільки передбачено складання та оформлення власних бізнес-планів, проектів відповідно до концепції діяльності підприємств, якщо підприємство міжнародне, такі завдання готуються іноземною мовою, внаслідок чого студенти отримують можливість розвивати та вдосконалювати вміння збору i аналізу інформацї, засвоювати знання галузей подальшої майбутньої діяльності, отримувати реальний досвід ділової комунікації.

В Італії під час навчання майбутніх економістів в закладах вищої освіти, є також увага до вододіння іноземною мовою та підвищення рівня мовної компетентності майбутніх спеціалістів до просунутого (європейського В2, C1 [7]). Саме тому ітадійські педагоги-науковці приділяють особливу увагу додатковій іншомовній комунікативній підготовці, яка, проте, здійснюеться студентами самостійно. Оскільки організувати процес вивчення мови не всім студентам 
вдаеться самостійно, викладачі прибігають до систем спецкурсів та лінгвістичних тренінгів, спрямованих на підготовку студентів до дінгвасамоосвітньої діяльності. Програма організації такої додаткової підготовки почала діяти з 2003 року, коди іноземна мова за професійним спрямуванням стала обов'язковим компонентом навчальної програми. Окрім того, італійські методисти зауважують, що вивчення мови не лише очно, а й самостійно має бути побудоване згідно з відомою концепцією міжпредметного мовного інтегрування (CLIL - Content and Language Integrated Learning) [20, с. 35]. Згідно 3 вимогами італійських навчальних програм, підготовка майбутніх спеціалістів доуспішноїпрофесійноїдіяльності передбачає володіння та оперування професійними, лінгвістичними, психологічними, міжкультурними знаннями, набутими як очно, так і самостійно [31]. Ефективний процес такої підготовки складається 3 гармонійного поєднання традиційних форм навчання та сучасних інтерактивних технологій, які сприяють розвитку критичного мислення, мотивації до самовдосконалення та саморозвитку [20, с. 32-53.].

У вітчизняній педагогіці питання організації лінгвосамоосвіти та лінгвосамоосвітньої діяльності також набувають актуальності: приділяеться увага механізмам формування відповідних вмінь, формам та методам її організації тощо. Дослідженням лінгвосамоосвітньої діяльності займадися О. Биконя, А. Білоусова, С. Боднар, І. Задорожна, О. Шумський та інші, проте науковці відзначають складність означеного феномену та підкреслюють необхідність подальшої наукової розвідки.

Висновки та перспективи подадыших досліджень. Підсумовуючи окреслене раніше, зазначимо, що невід'ємною складовою іншомовної підготовки майбутніх економістів у закладі вищої освіти є лінгвосамоосвіта, як самостійна пізнавадьна діядьність студента, спрямована на оволодіння іноземною мовою. Ії продуктивність і результативність залежить від комплексу вмінь, які, в свою чергу, потребують розвитку. Вивчення зарубіжного і вітчизняного досвіду організації лінгвосамоосвіти майбутніх економістів, свідчать про необхідність коригування змісту освітнього процесу, зокрема перенесення акценту на організацію самоосвітньої діяльності студентів, активізацію і підтримку процесу їх самовдосконалення як під час навчання в університеті, так і після його закінчення.

В той же час потребують подадьшого вивчення форми і методи активізації дінгвосамоосвітньої діяльності майбутніх економістів в процесі професійної підготовки. 


\section{References:}

1. Антонова О. Є. Методичні рекомендації до застосування технології формування у майбутніх учителів базових знань з курсу «Педагогіка» / За ред. О. А. Дубасенюк. - Житомир : Житомирський державний педагогічний ун-т імені Івана Франка, 2000. - 100 с

2. Атяскина, Т.В. Формирование умений самообразования будущих техниковпрограммистов в профессиональном колледже / Т.В. Атяскина // Среднее профессиональное образование. - 2015. - №7. - С. 45-47.

3. Бобыкина И.А. Система формирования лингвосамообразовательной компетентности будущих учителей в процессе профессиональнопедагогической подготовки. - Вопросы гуманитарных наук. - 2003. - №1. C. $302-305$.

4. Гальскова Н. Д., Никитенко Н. 3. Теория и практика обучения иностранным языкам. Начальная школа: метод. пособие. - Москва: Айрис Пресс, 2004. 240 c.

5. Гончаренко С. Український педагогічний словник. - К. : Либідь, 1997. - 366 с.

6. Есиппович К. Б. Управление познавательной деятельностью учащихся при изучении иностранных языков в средней школе: учеб. пособие. - Москва: Просвещение, 1998. - 190 с.

7. Загальноєвропейські компетенції володіння іноземною мовою: вивчення, викладання, оцінка (Common European Framework of Reference for Languages: Learning, Teaching and Assessment). Київський національний університет імені Тараса Шевченка: офіційний сайт. URL: http://www.univ.kiev.ua/ua/ resources/tests4 (дата звернення: 5.05.2016).

8. Інноваційна освітня діяльність: регіональні аспекти : тези Міжнар. наук.практ. конф. (14-15 квіт. 2011 р., м. Біла Церква) / за наук. ред. В. В. Олійника, Н. І. Клокарь, А. М. Карамушки, В. В. Аапинського. - Біла Церква : [б. в.], $2011-220$ c.

9. Леонтьев А. А. Психология обучения. Москва: Наука, 1997. 175 с.

10. Мішин C.M. Теоретичне обгрунтування поняття “самоосвіта" в процесі професійної педагогічної діяльності майбутнього фахівця // Фізичне виховання, спорт і культура здоров'я у сучасному суспільстві : збірник наукових праць... № 2 (18), 2012. - С. 74 - 77.

11. Решетова Е. Е. Психологическая готовность педагогов дополнительного образования к культуродогической работе с подростками: дис. ... канд. псих. наук: 19.00.07 / Нижегород. пед. ун-т. Нижний Новгород, 2014. 178 с.

12. Сидорчук Н.Г. Роль самостійної навчальної діяльності у підготовці майбутніх учителів до професійної самоосвіти / Н.Г. Сидорчук // Професійна підготовка педагогічних працівників: наук.-метод. зб. / за ред. О.А. Дубасенюк, А.П. Пуховської. - Київ-Житомир: Житомир. держ. пед.у н-тет. - 2000. - С.254262. - 0,5 др. арк. 
13. Соломински Е. Особенности системы высшего образования Германии глазами российского профессора (интервью с Э. Патриком) // Высшее образование в России. 2014. № 2. С. 131 - 141.

14. Соціологія: словник термінів і понять: упоряд. Є.А. Біленький, В.М. Дебой, М.А. Козловець та ін..; ред. Є.А. Біленький, М.А. Козловець. Київ: Кондор, 2006. $372 \mathrm{c}$.

15. Спирина Т. А. Зарубежный и отечественный опыт индивидуализации обучения в высшей школе // Мир науки, культуры, образования. 2014. № 3. C. $110-113$.

16. Стариченко Б. Е. Синхронная и асинхронная организация учебного процесса в вузе на основе инфор-мационно-технологической модели обучения // Педагогическое образование в России. 2013. № 3. С. 23 - 31.

17. Філософський енциклопедичний словник: довідкове видання. Київ: Абрис, 2002. $742 \mathrm{c}$.

18. Blended Learning, Course Redesign and New Access to Education: Teaching English / edited by B. Tomlinson and K. Whittaker. London, 2013. 258 p.

19. Calabrese R., Dawes B.. Early language learning and teacher training: a foreign language syllabus for primary school teachers. Studi di Glottadidattica. 2008. №1. P. 32-53.

20. CLIL 2010 Conference Blog and CLIL Café (Eichstätt, Germany, 30.09-2.10.2010). URL: http://clil2010.wordpress.com/

21. Schelten A. Einführung in die Berufspedagogik. Stuttgart, Steiner. 1991. 154 p.

\section{Transliteration of References:}

1. Antonova O. Ye. (2000). Metodychni rekomendatsii do zastosuvannia tekhnolohii formuvannia u maibutnikh uchyteliv bazovykh znan z kursu «Pedahohika» / Za red. O. A. Dubaseniuk. - Zhytomyr : Zhytomyrskyi derzhavnyi pedahohichnyi un-t imeni Ivana Franka.

2. Atyaskina, T.V. (2015). Formirovanie umenij samoobrazovaniya budushchih tekhnikov-programmistov v professional'nom kolledzhe / T.V. Atyaskina // Srednee professional'noe obrazovanie. №7. S. 45-47.

3. Bobykina I.A. (2003) Sistema formirovaniya lingvosamoobrazovatel'noj kompetentnosti budushchih uchitelej v processe professional'no-pedagogicheskoj podgotovki. - Voprosy gumanitarnyh nauk. №1. S. $302-305$.

4. Gal'skova N. D., Nikitenko N. Z. Teoriya i praktika obucheniya inostrannym yazykam. Nachal'naya shkola: metod. posobie. (2004) Moskva: Ajris Press. 240 s.

5. Honcharenko S. (1997) Ukrainskyi pedahohichnyi slovnyk. K. : Lybid. 366 s.

6. Esippovich K. B. (1998). Upravlenie poznavatel'noj deyatel'nost'yu uchashchihsya pri izuchenii inostrannyh yazykov v srednej shkole: ucheb. posobie. Moskva: Prosveshchenie. 190 s. 
7. Zahalnoievropeiski kompetentsii volodinnia inozemnoiu movoiu: vyvchennia, vykladannia, otsinka (Common European Framework of Reference for Languages: Learning, Teaching and Assessment). Kyivskyi natsionalnyi universytet imeni Tarasa Shevchenka: ofitsiinyi sait. URL: http://www.univ.kiev.ua/ua/resources/ tests4 (data zvernennia: 5.05.2016).

8. Innovatsiina osvitnia diialnist: rehionalni aspekty : tezy Mizhnar. nauk.-prakt. konf. (14-15 kvit. 2011 r., m. Bila Tserkva) / za nauk. red. V. V. Oliinyka, N. I. Klokar, L. M. Karamushky, V. V. Lapynskoho. - Bila Tserkva : [b. v.], 2011 - 220 s.

9. Leont'ev A. A. (1997). Psihologiya obucheniya. Moskva: Nauka. 175 s.

10. Mishyn S.M. (2012). Teoretychne obgruntuvannia poniattia "samoosvita" v protsesi profesiinoi pedahohichnoi diialnosti maibutnoho fakhivtsia // Fizychne vykhovannia, sport i kultura zdorovia u suchasnomu suspilstvi : zbirnyk naukovykh prats... № 2 (18). C. $74-77$.

11. Reshetova E. E. (2014). Psihologicheskaya gotovnost' pedagogov dopolnitel'nogo obrazovaniya k kul'turologicheskoj rabote s podrostkami: dis. ... kand. psih. nauk: 19.00.07 / Nizhegorod. ped. un-t. Nizhnij Novgorod. $178 \mathrm{~s}$.

12. Sydorchuk N.H. (2000). Rol samostiinoi navchalnoi diialnosti u pidhotovtsi maibutnikh uchyteliv do profesiinoi samoosvity / N.H. Sydorchuk // Profesiina pidhotovka pedahohichnykh pratsivnykiv: nauk.-metod. zb. / za red. O.A. Dubaseniuk, L.P. Pukhovskoi. - Kyiv-Zhytomyr: Zhytomyr. derzh. ped.u n-tet. S. 254-262.

13. Solominski E. (2014). Osobennosti sistemy vysshego obrazovaniya Germanii glazami rossijskogo professora (interv'yu s E. Patrikom) // Vysshee obrazovanie v Rossii. № 2. S. 131 - 141.

14. Sotsiolohiia: slovnyk terminiv i poniat: uporiad. Ye.A. Bilenkyi, V.M. Deboi, M.A. Kozlovets ta in..; red. Ye.A. Bilenkyi, M.A. Kozlovets. (2006). Kyiv: Kondor. 372 s.

15. Spirina T.A.(2014). Zarubezhnyj i otechestvennyj opyt individualizacii obucheniya v vysshej shkole // Mir nauki, kul'tury, obrazovaniya. № 3. S. 110 - 113.

16. Starichenko B. E. (2013). Sinhronnaya i asinhronnaya organizaciya uchebnogo processa v vuze na osnove infor-macionno-tekhnologicheskoj modeli obucheniya // Pedagogicheskoe obrazovanie v Rossii. № 3. S. 23 - 31.

17. Filosofskyi entsyklopedychnyi slovnyk: dovidkove vydannia. (2002). Kyiv: Abrys. $742 \mathrm{~s}$.

18. Blended Learning, Course Redesign and New Access to Education: Teaching English / edited by B. Tomlinson and K. Whittaker. (2013). London. 258 p.

19. Calabrese R., Dawes B. (2008). Early language learning and teacher training: a foreign language syllabus for primary school teachers. Studi di Glottadidattica. №1. P. 32-53.

20. CLIL 2010 Conference Blog and CLIL Café (Eichstätt, Germany, 30.09-2.10.2010). URL: http://clil2010.wordpress.com/

21. Schelten A. (1991). Einführung in die Berufspedagogik. Stuttgart, Steiner. 154 p. 
The Author

Bogdan Chernyavsky

Postgraduate Student,

Zaporizhia National University,

Zaporizhia, Ukraine

E-mail: b.cherniavskyi1992@gmail.com

Abstracts

БОГДАН ЧЕРНЯВСЬКИЙ. Теоретичні основи формування у майбутніх економістів вмінь дінгво-самоосвіти. У статті розкрито сутність лінгвосамоосвіти, проаналізовано особливості лінгвосамоосвітньої діяльності майбутніх економістів. Виокремлено та схарактеризовано перелік вмінь, які забезпечують ефективність лінгвосамоосвітньої діяльності майбутніх економістів, розкрито вітчизняний та зарубіжний досвід їх формування.

Ключові слова: лінгвосамоосвіта, майбутні економісти, лінгосамоосвітня діяльність майбутніх економістів, вміння лінгвосмаоосвіти, підготовка.

БОГДАН ЧЕРНЯВСКИЙ. Теоретические основы формирования у будущих экономистов умения дингво-самообразования. В статье раскрыта сущнность лингвосамообразования, проанализированы особенности лингвосамоообразовательной деятельности будущцх экономистов. Выделен и охарактеризован перечень умений, обеспечивающих эффективность лингвосамообразовательной деятельности будущих экономистов, раскрыт отечественный и зарубежный опыт их формирования.

Ключевые слова: лингвасамообразование, будущие экономисты, лингвосамообразовательная деятельность будущих экономистов, умения лингвосамообразования, подготовка.

BOHDAN CZERNIAWSKI. Teoretyczne podstawy kształtowania umiejętności językowych i samokształcenia u przyszłych ekonomistów. Artykut przedstawia istotę samokształcenia lingwistycznego, analizuje cechy dziatalności samokształcenia językowego przyszłych ekonomistów. Wyszczególniono i scharakteryzowano listę 
umiejętności zapewniajacych skuteczność lingwistycznych działań samokształceniowych przyszłych ekonomistów, przedstawiono krajowe $i$ zagraniczne doświadczenia z zakresu ich formowania.

Słowa kluczowe: samokształcenie jezykowe, przyszli ekonomiści, działalność samokształcenia językowego przyszłych ekonomistów, umiejętność samokształcenia językowego, szkolenie. 